\title{
The Highest Seawater Level Along the Upper Gulf of Thailand in 100 Years
}

\author{
Cherdvong Saengsupavanich* \\ Kasetsart University, Thailand
}

Submission: August 08, 2017; Published: October 05, 2017

*Corresponding author: Cherdvong Saengsupavanich, Faculty of International Maritime Studies, Kasetsart University, Sri Racha, 199 Moo 6 Sukhumvit Rd., Tungsukla, Sri Racha, Chonburi, 20230, Thailand, Tel: +66 897666086; Fax: +66 38352607;

Email: cherdvong.saengsupavanich@hotmail.com /cherdvong.s@ku.ac.th

\begin{abstract}
Information on seawater level in extreme cases is crucial for coastal engineering and management. This research predicts the 100year seawater level along the upper Gulf of Thailand. Long-term tidal records were gathered from the Marine Department at 3 stations, being Bang Pakong tidal station in Samutprakan province, Ta Chen tidal station in Samutsakhon province, and Mae Klong tidal station in Samutsongkhram province. The records covered more than 35 years. The annual highest high seawater levels were identified for each station. The Extreme value analysis from ordered data was utilized. All tidal stations along the upper Gulf of Thailand indicated an increasing trend of the seawater level. The highest seawater level in 100 years at Bang Pakong, Ta Chen, and Mae Klong tidal stations were expected to be $+2.14 \mathrm{~m}$ MSL, $+2.42 \mathrm{~m} \mathrm{MSL}$, and $+2.30 \mathrm{~m}$ MSL respectively. Applications of the results can be used for designs of coastal structure or implementation of coastal management schemes.
\end{abstract}

Keywords: Sea level; Coastal engineering and management; Upper Gulf of Thailand; Coastal erosion and inundation

\section{Introduction}

The coastal area is susceptible to natural hazards such as coastal erosion and inundation [1-5]. The upper gulf of Thailand has experienced severe coastal erosion originated from both natural causes and human activities [6]. The erosion created by seasonal big waves attacking the shoreline is accelerated by ponds and mangrove destruction. However, developments along

the upper gulf of Thailand continue to grow. Many coastal and marine infrastructures have been constructed in Chachoengsao province, Samutprakan province, Bangkok metropolitan, Samutsakhon province, and Samutsongkhram province (Figure 1). These urban expansions need proper planning and protection from natural hazards.

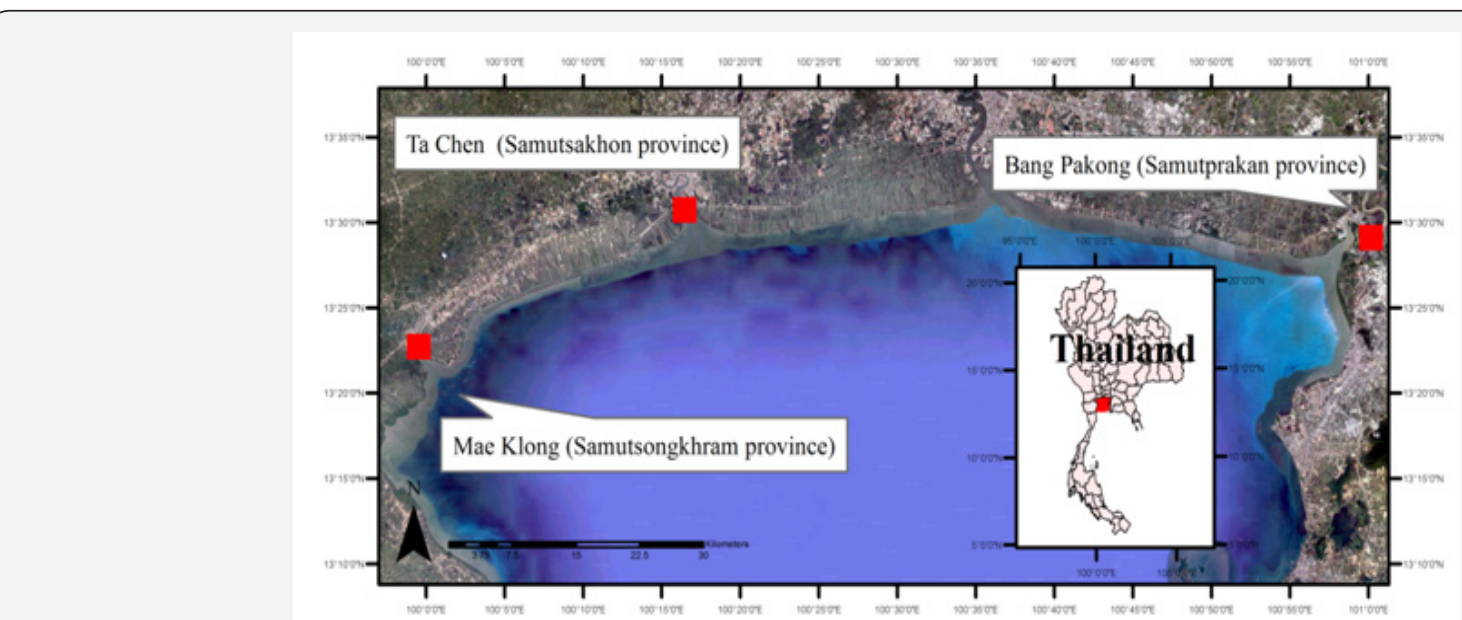

Figure 1: The upper Gulf of Thailand and the interested tidal stations. 
Seawater level is one of the most important parameters that coastal engineers and managers concern as it is directly related to severity of waves attacking the coastline as well as coastal flooding. Misestimating the seawater level during an extreme incident can lead to unacceptable outcomes. From a coastal engineering aspect, the wave height attacking the coastline is the utmost important design parameter. A basic coastal engineering rule of thumb suggests that the breaking wave height is 0.78 times the water depth. If the actual water level is $0.5 \mathrm{~m}$ higher than the estimation, the wave height will be $0.39 \mathrm{~m}$ bigger, resulting in a possible failure of coastal protection structures. In a case of revetment design, the rock should be $260 \mathrm{~kg}$ to withstand a 1-meter wave height but the weight should increase to $710 \mathrm{~kg}$ to resist a wave height of 1.39 meters. If a pier is to be built, the elevation of the deck must be above the design water level. Incorrect water level estimation can result in the deck being under water during a storm [7]. From a coastal manager's aspect, water level prediction is a necessary factor in various managerial actions such as the setback line and coastal land use zoning [8]. The residential area should be located outside the risk-prone zone to avoid inundation. Tourism activities should be warned about the dangerous zone where the seawater level may rise and pose a threat to life. Therefore, predictions of the seawater level along the upper Gulf of Thailand during extreme cases are the focus of this research. The results can be useful for academia and coastal practitioners.

Table 1: Tidal stations along the upper Gulf of Thailand in this study.

\begin{tabular}{|c|c|c|c|}
\hline Tidal station & Latitude & Longitude & Duration \\
\hline Bang Pakong (Samutprakan province) & $13^{\circ} 29^{\prime} 06 »$ & $101^{\circ} 00^{\prime} 11 »$ & $1981-2015$ \\
\hline Ta Chen (Samutsakhon province) & $13^{\circ} 30^{\prime} 42 »$ & $100^{\circ} 16^{\prime} 28 »$ & $1977-2015$ \\
\hline Mae Klong (Samutsongkhram province) & $13^{\circ} 22^{\prime} 42 »$ & $99^{\circ} 59^{\prime} 32 »$ & $1977-2015$ \\
\hline
\end{tabular}

\section{Materials and Methods}

Long-term tidal records were gathered from the Marine Department at 3 stations along the upper Gulf of Thailand (Table 1). The tidal statistics covered 38 years. A parameter used in this study was the highest high water (HHW), which is the highest seawater level occurring in each calendar year. The time series of HHW of each station was plotted, indicating a trend of seawater level rise/fall. After the time-series of the annual highest seawater level was acquired, the Extreme value analysis from ordered data was utilized [8]. Firstly, individual data was ranked in a deceasing order. Since only extreme values of the seawater level and their ranking were known, the ranking was converted into a plotting position, representing probability of exceedence (Q) (Eq. 1).

$$
Q=\frac{i-c_{1}}{N+c_{2}}
$$

where $\mathrm{i}$ is the ranking of the data point, $\mathrm{N}$ is the total number of points, and $\mathrm{c} 1$ and $\mathrm{c} 2$ are the constants for unbiased plotting position (Eq. 2 and Eq. 3). In this study, the Weibull distribution was used because it has a flexibility to adjust the curvature of the

Table 2: The HHW at Bang Pakong tidal station during 1981-2015.

\begin{tabular}{|c|c|c|c|c|c|}
\hline Year & HHW (m MSL) & Year & HHW (m MSL) & Year & 2005 \\
\hline 1981 & +1.77 & 1993 & +1.65 & 2006 \\
\hline 1982 & +1.75 & 1994 & +1.64 & 2007 \\
\hline 1983 & +1.75 & 1995 & +1.78 & +1.72 & 2008 \\
\hline 1984 & +1.78 & 1996 & +1.95 & 2009 \\
\hline 1985 & +1.78 & 1997 & +1.79 & 2010 \\
\hline 1986 & +1.83 & 1998 & +1.88 & 2011 \\
\hline 1987 & +1.79 & 1999 & +2.11 & 2.01 \\
\hline 1988 & +1.78 & 2000 & & 2012 \\
\hline
\end{tabular}


Fisheries and Oceanography Open Access Journal

\begin{tabular}{|l|l|l|l|l|l|}
\hline 1989 & +1.66 & 2001 & +2 & 2013 & 2014 \\
\hline 1990 & +1.86 & 2002 & +1.92 & 2015 & 1.75 \\
\hline 1991 & +1.78 & 2003 & +1.81 & & 1.78 \\
\hline 1992 & +1.66 & 2004 & +1.92 & & \\
\hline
\end{tabular}

Table 3: The predicted HHW at Bang Pakong tidal station.

\begin{tabular}{|c|c|}
\hline Return period (years) & HHW (m MSL) \\
\hline 50 & +2.1 \\
\hline 75 & +2.12 \\
\hline 100 & +2.14 \\
\hline
\end{tabular}

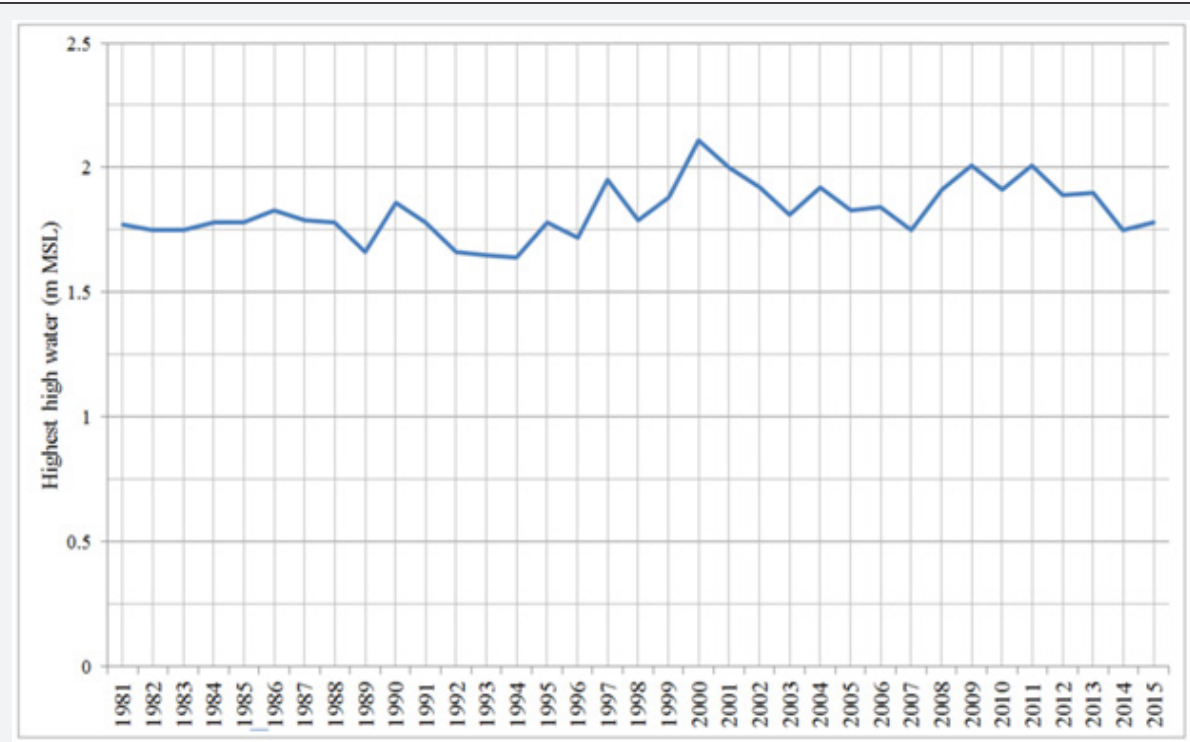

Figure 2: The HHW at Bang Pakong tidal station during 1981-2015.

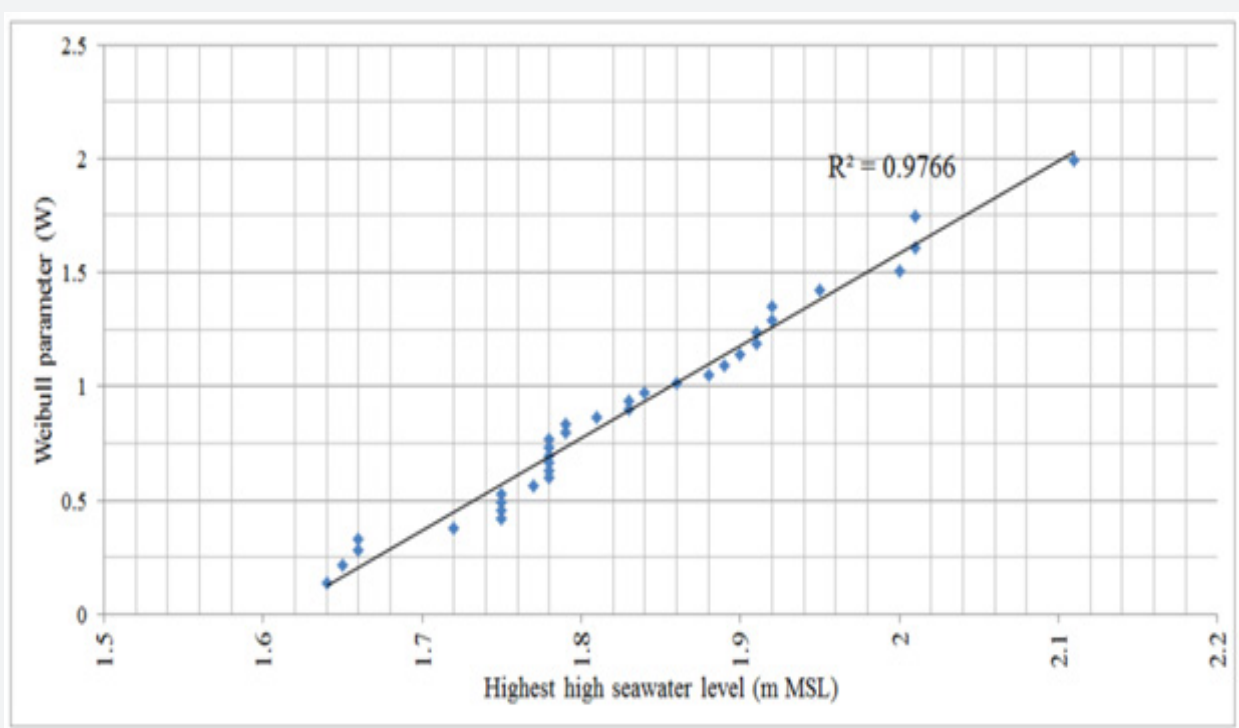

Figure 3: The result of the Extreme value analysis at Bang Pakong tidal station.

\section{Samutsakhon province (ta chen tidal station)}

In Samutsakhon province, the annual HHW also presented an increasing trend (Table 4 \& Figure 4). The annual HHW ranged from $+1.37 \mathrm{~m}$ MSL to $+2.35 \mathrm{~m}$ MSL. After the Extreme value analysis was undertaken, it was found that the value that yielded the highest R2 was 10.7 (Figure 5). The HHW in 100 years at Ta Chen tidal station was anticipated to be $2.42 \mathrm{~m}$ MSL (Table 5). 
Fisheries and Oceanography Open Access Journal

Table 4: The HHW at Ta Chen tidal station during 1977-2015.

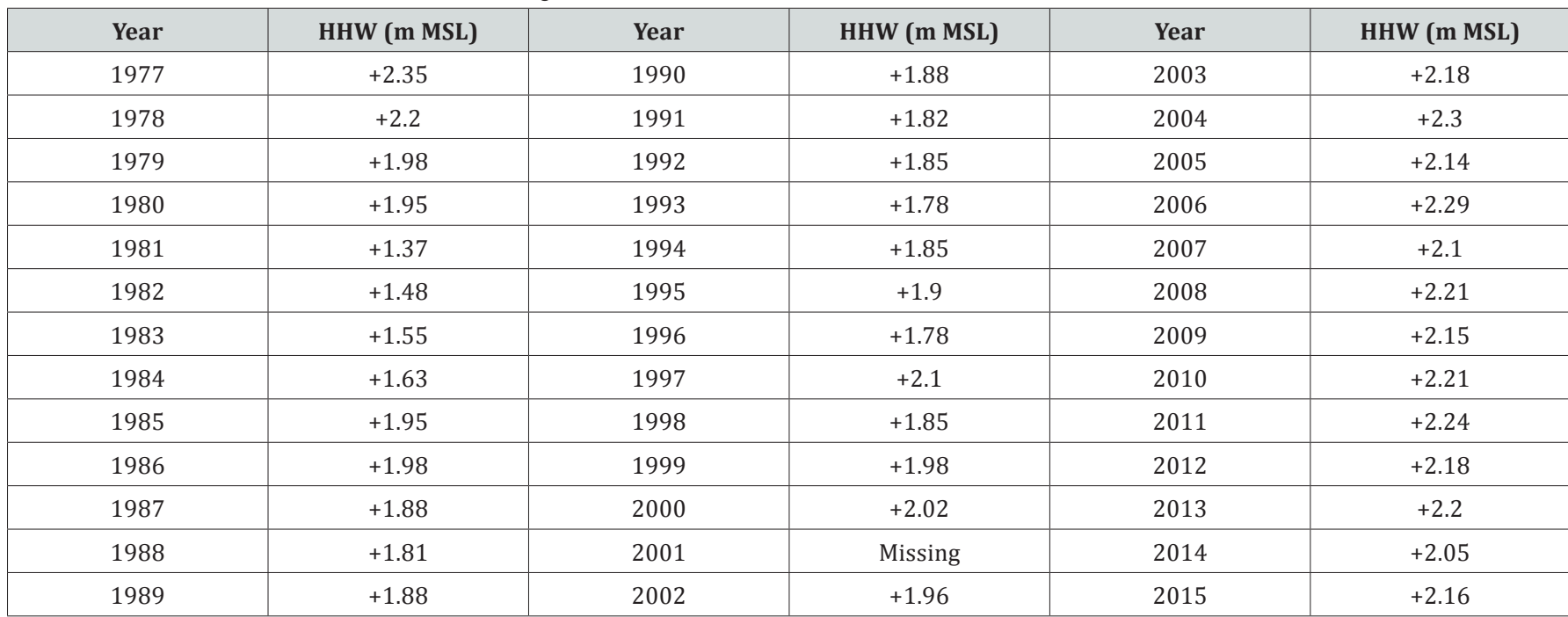

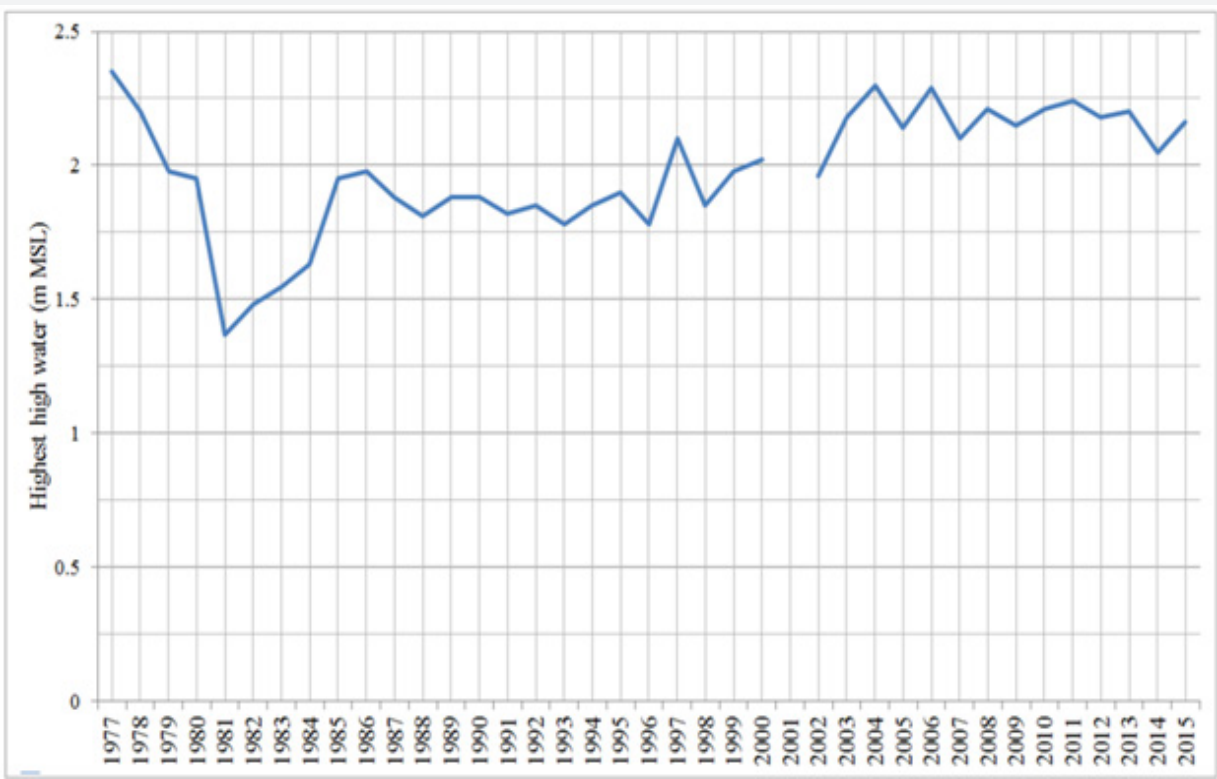

Figure 4: The HHW at Ta Chen tidal station during 1977-2015.

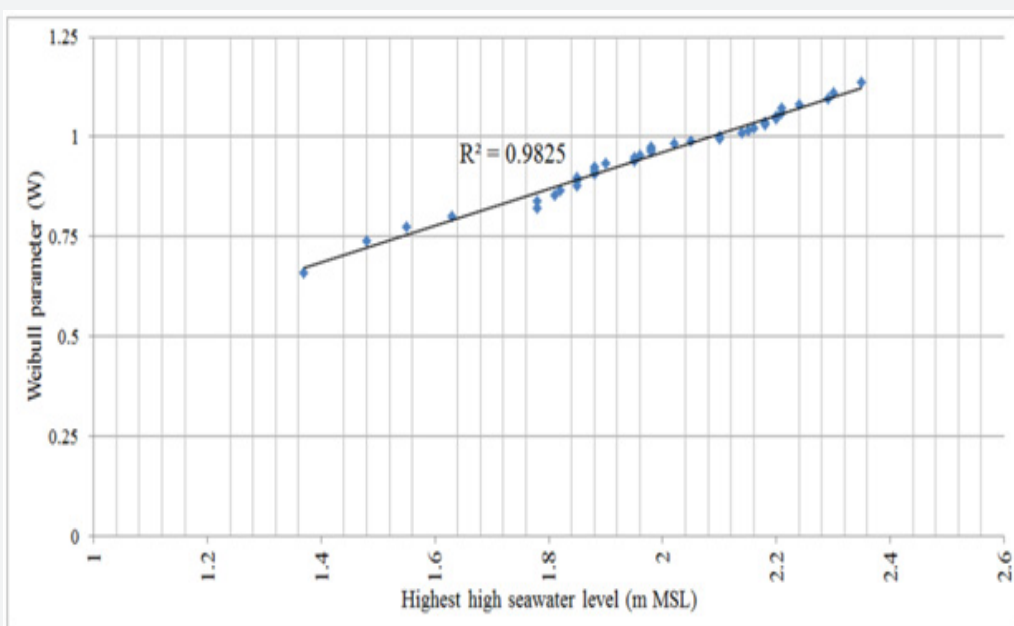

Figure 5: The result of the Extreme value analysis at Ta Chen tidal station. 
Table 5: The predicted HHW at Ta Chen tidal station.

\begin{tabular}{|c|c|}
\hline Return period (years) & HHW (m MSL) \\
\hline 50 & +2.38 \\
\hline 75 & +2.4 \\
\hline 100 & +2.42 \\
\hline
\end{tabular}

\section{Samutsongkhram province (mae klong tidal station)}

In Samutsongkhram province, the annual HHW also showed an increasing trend (Table $6 \&$ Figure 6). The annual HHW varied from $+1.46 \mathrm{~m}$ MSL to $+2.22 \mathrm{~m}$ MSL. After the Extreme value analysis was completed, it was found that the value that yielded the highest R2 was 5.0 (Figure 7). The HHW in 100 years at Mae Klong tidal station was forecasted to be $2.30 \mathrm{~m}$ MSL (Table 7).

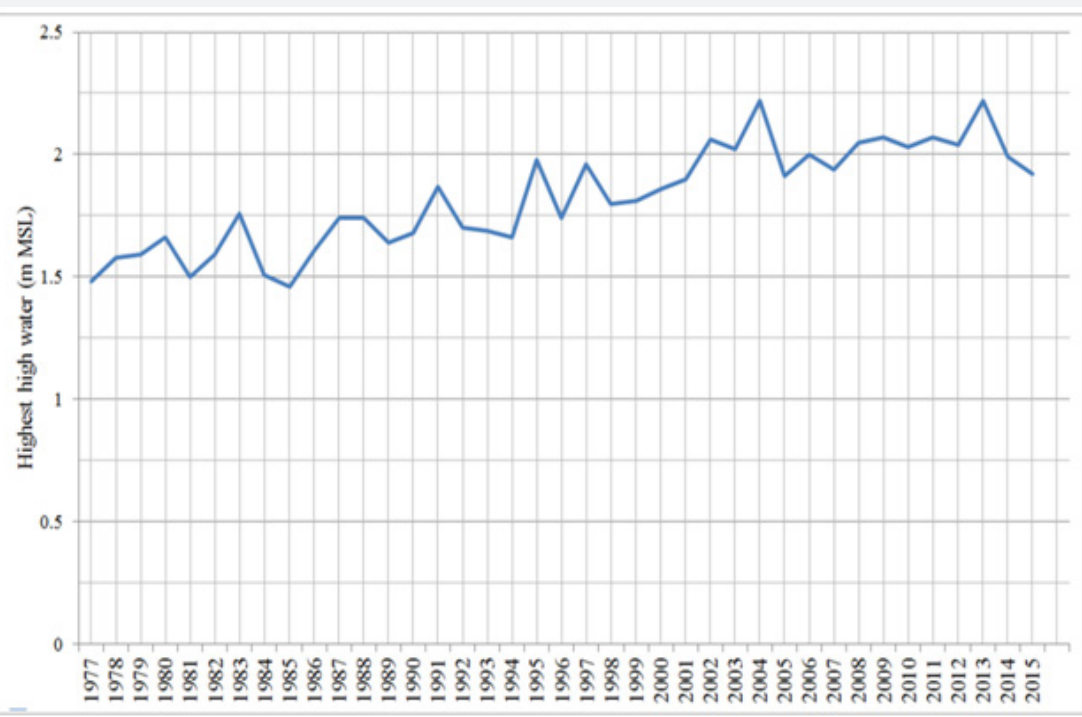

Figure 6: The HHW at Mae Klong tidal station during 1977-2015.

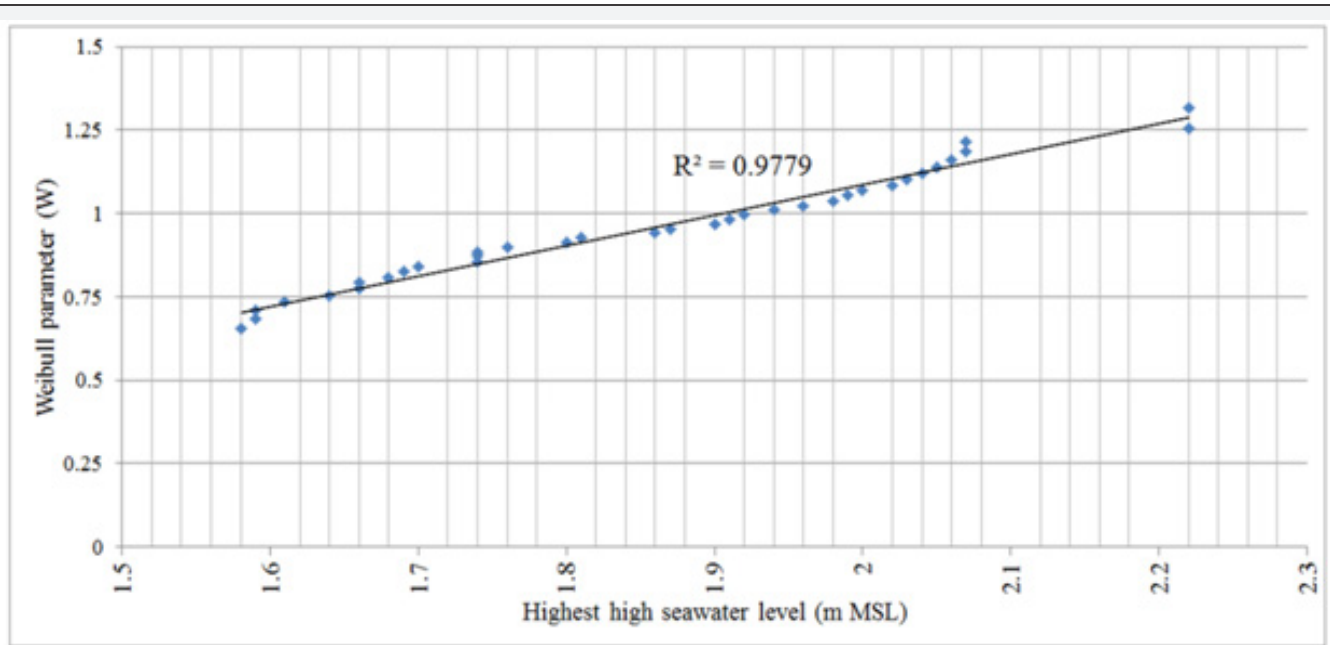

Figure 7: The result of the Extreme value analysis at Mae Klong tidal station.

Table 6: The HHW at Mae Klong tidal station during 1977-2015.

\begin{tabular}{|l|c|c|c|c|c|}
\hline Year & HHW (m MSL) & Year & HHW (m MSL) & Year & HHW (m MSL) \\
\hline 1977 & +1.48 & 1990 & +1.68 & 2003 & +2.02 \\
\hline 1978 & +1.58 & 1991 & +1.87 & 2004 & +2.22 \\
\hline 1979 & +1.59 & 1992 & +1.7 & 2005 & +1.91 \\
\hline 1980 & +1.66 & 1993 & +1.69 & 2006 & +2 \\
\hline 1981 & +1.5 & 1994 & +1.66 & 2007 & +1.94 \\
\hline 1982 & +1.59 & 1995 & +1.98 & 2008 & +2.05 \\
\hline 1983 & +1.76 & 1996 & +1.74 & 2.07 \\
\hline
\end{tabular}


Fisheries and Oceanography Open Access Journal

\begin{tabular}{|l|c|c|c|c|c|}
\hline 1984 & +1.51 & 1997 & +1.96 & 2010 & +2.03 \\
\hline 1985 & +1.46 & 1998 & +1.8 & 2011 & +2.07 \\
\hline 1986 & +1.61 & 1999 & +1.81 & 2012 & +2.04 \\
\hline 1987 & +1.74 & 2000 & +1.86 & 2014 & +2.22 \\
\hline 1988 & +1.74 & 2001 & +1.9 & 2015 & +1.99 \\
\hline 1989 & +1.64 & 2002 & +2.06 & +1.92 \\
\hline
\end{tabular}

Table 7: The predicted HHW at Mae Klong tidal station.

\begin{tabular}{|c|c|}
\hline Return period (years) & HHW (m MSL) \\
\hline 50 & +2.25 \\
\hline 75 & +2.28 \\
\hline 100 & +2.3 \\
\hline
\end{tabular}

Discussion and Conclusion

Extreme seawater level is crucial for coastal engineering and management. Many coastal issues occurred along the upper Gulf of Thailand such as coastal inundation and coastal erosion. To address those problems, information on the expected seawater level must be accurately provided. This research gathered past tidal records during 1977 to 2015 from the Marine Department and applied the Extreme value analysis to forecast the 100year seawater level. The main objective of this research was to quantitatively identify how much the 100-year HHW might be, so that various coastal structures could be suitably designed and coastal management schemes could be effectively implemented.

All tidal stations along the upper Gulf of Thailand suggested an increasing trend of seawater level. The highest seawater level in 100 years at Bang Pakong, Ta Chen, and Mae Klong tidal stations were expected to be $+2.14 \mathrm{~m} \mathrm{MSL},+2.42 \mathrm{~m}$ MSL, and $+2.30 \mathrm{~m}$ MSL respectively. After realizing the possible seawater level in an extreme case, coastal engineers will be able to configure coastal structures such as crest elevation of a breakwater, rock size of a revetment, or deck elevation of a pier. Coastal managers will be able to draw a setback line to manage coastal inundation. These actions cannot be completed unless the HHW in extreme cases are available.

\section{References}

1. Cao W, Wong MH (2007) Current status of coastal zone issues and management in China: a review. Environ Int 33(7): 985-992.

2. Cong LV, Cu NV, Shibayama T (2014) Assessment of Vietnam Coastal Erosion and Relevant Laws and Policies. In: Thao ND, Takagi H, Esteban M (Eds.), Coastal Disasters and Climate Change in Vietnam: Engineering and Planning Perspectives, Elsevier, pp. 81-106.

3. Fitton JM, Hansom JD, Rennie AF (2016) A national coastal erosion susceptibility model for Scotland. Ocean \& Coastal Management 132: 80-89.

4. Rangel-BNG, Anfuso G, Williams AT (2015) Coastal erosion along the Caribbean coast of Colombia: Magnitudes, causes and management. Ocean \& Coastal Management 114: 129-144.

5. Saengsupavanich C, Chonwattana S, Naimsampao T (2009) Coastal erosion through integrated management: A case of Southern Thailand. Ocean \& Coastal Management 52(6): 307-316.

6. Saengsupavanich C (2013) Erosion protection options of a muddy coastline in Thailand: Stakeholders' shared responsibilities. Ocean \& Coastal Management 83: 81-90.

7. Padron DV, Paparis B (2004) Port-related marine structures. In: Tsinker GP (Ed.), Port Engineering: Planning, Construction, Maintenance, and Security, John Wiley \& Sons, pp. 65-184.

8. Kamphuis JW (2010) Introduction to coastal engineering and management. (2nd edn), World scientific, Singapore.

9. Saramul S, Ezer T (2014) Spatial variations of sea level along the coast of Thailand: Impacts of extreme land subsidence, earthquakes and the seasonal monsoon. Global and Planetary Change 122: 70-81.

10. Trisirisatayawong I, Naeije M, Simons W, Fenoglio-ML (2011) Sea level change in the Gulf of Thailand from GPS-corrected tide gauge data and multi-satellite altimetry. Global and Planetary Change 76: 137-151.

\section{Your next submission with Juniper Publishers will reach you the below assets}

- Quality Editorial service

- Swift Peer Review

- Reprints availability

- E-prints Service

- Manuscript Podcast for convenient understanding

- Global attainment for your research

- Manuscript accessibility in different formats

( Pdf, E-pub, Full Text, Audio)

- Unceasing customer service

Track the below URL for one-step submission https://juniperpublishers.com/online-submission.php 